\title{
Brewing the Recipe for Beer Brand Equity
}

\author{
Cristina Calvo Porral ${ }^{1}$, Normand Bourgault ${ }^{2}$, Domingo Calvo Dopico ${ }^{3}$
}

\begin{abstract}
:
This research study aims to analyze the sources and consequences of beverages' Brand Equity, and more specifically, the beer Brand Equity in a Sothern European mature market. For this purpose, based on the customer-based Aaker's Brand Equity model, we developed an empirical study, using structural equation modeling (SEM) in order to assess how beer Brand Equity stems from in the brewery industry and to analyze its consequences in consumer behavior. Our findings suggest that the beer brand image is the most important dimension for beer Brand Equity. Moreover, a significant positive influence was found for all the dimensions analyzed, namely brand awareness, perceived quality and loyalty; while we found empirical support for the influence of beer Brand Equity on purchase intention and the consumer willingness to pay a premium price. This research brings relevant implications for brewery marketing managers, who should strengthen their beer brand image, and further consider beer Brand Equity as a key variable in consumer behaviour.
\end{abstract}

\section{Key Words:}

brand equity, brand loyalty, brand awareness, beverage sector, beer

JEL Classification : M31, M30

\footnotetext{
${ }^{I}$ Corresponding author: Marketing and Market Research Department, Economics and Business Administration Faculty Campus Elviña s/n, University of La Coruña (Spain), e-mail: ccalvoccalvo@udc.es

${ }^{2}$ Marketing Department, Pavillon Lucient Beault, B2084, 101 Rue Saint Jean Bosco,

University of Outaouais (Canada), e-mail: normand.bourgault@uqo.ca

${ }^{3}$ Marketing and Market Research Department, Economics and Business Administration Faculty

Campus Elviña s/n, University of La Coruña (Spain), e-mail: domingo@udc.es
} 


\section{Introduction}

The beverage industry and specifically the brewery sector is a key economic industry within the European agribusiness scenario. However, there are only few studies on beer brand value from the consumers' standpoint (Atilgan et al., 2005); and most of the researches had focused in the variables of marketing mix influencing consumers, such as price, communication, distribution or advertising (Yoo et al., 2000). Nevertheless, in the purchasing process, consumers are not only concerned about the price or quality of a product or brand, but also other variables such as the Brand Equity or value. Brand equity is an intangible asset, being a source of long-term competitive advantage in the marketplace, which cannot be completely understood without carefully analyzing its sources, or the variables related to its formation in consumers' mind. This research develops and empirical study applying the Aaker's Brand Equity model, in order to analyze the sources Brand Equity for a product with a great popularity and strong demand -that is, beer-, in specific European mature market -the Spanish marketplace-.This research is organized as follows. It begins with the theoretical foundations; then the objectives are set out; in the fourth section the methodology is explained, as well as the simple, the selected variables and the measurement scales used; next, the results are discussed, to end with some conclusions, implications and the research limitations.

\section{Theorical Framework}

\subsection{Brand Equity conceptualization}

Building strong brands has become a marketing priority for many companies nowadays because it provides multiple advantages to establish and create an identity in the market place for a company, while being a key source of competitive advantage (Aaker, 1996). In order to measure the overall value of a determinate brand or product, marketing researchers and managers have begun to examine the concept of Brand Equity (Aaker, 1991; Keller, 1993), which refers to the tremendous value a brand brings to consumers and manufacturers. Following Aaker (1991, 1996), Brand Equity could be conceptualized as all of those tangible assets of a brand, held in the mind of the consumers. More precisely, Farquhar (1989) defines Brand Equity as the added value that a brand brings to a particular product or service, and points out that Brand Equity is that set of assets and liabilities linked to a brand, its name or symbol, that incorporate or decrease the value provided by a product or service to the company or its customers. Keller (1993) defines Brand Equity as the differential effect of brand knowledge on the response given by consumers to the brand marketing.

The present research follows the theoretical model proposed by Aaker (1991), given that it represents an important reference for marketing scholars, through an integrative conceptualization of Brand Equity and because it has been empirically 
demonstrated by previous researches focused on manufacture brands (Yoo et al., 2000; Atilgan et al., 2005). Hence, we will define Brand Equity as the set of assets and liabilities linked to the brand, which either increase or decrease the value provided by a product or service to the consumer.

\subsection{The dimensions of beer Brand Equity}

Nevertheless, Brand Equity cannot be completely understood without carefully analyzing its determinants and sources, or the contributing variables to the formation of Brand Equity in the consumers' mind. In the purchasing process, consumers are not only concerned about the price or quality of a product or brand, but also other variables such as the brand awareness or brand image (Aaker, 1991, 1996). Additionally, this study aims to analyze two consequences of Brand Equity on consumer behavior. For that purpose, we have proposed the analysis of two other dimensions, such as the consumers' purchase intention and their willingness to pay a premium price for the one specific beer brand.

First dimension of beer Brand Equity is brand awareness. The level of brand awareness in Brand Equity depends on the level of noticeability that is achieved by a brand or even by a product in the marketplace. So the higher the level of awareness, the more dominant is the brand in the consumers' mind, and that will increase the likelihood of a brand to being considered in many purchase decisions (Aaker, 1996, Yoo et al., 2000). Many studies demonstrate that consumers who are able to recognize a brand name in a product category are more likely to purchase that brand, the reason is that familiar products are usually preferred to those that are less familiar (Hoyer, 1990). Therefore, when increasing the level of awareness of a specific beer brand, it increases the probability that the brand will be in the consideration set in a purchase decision. Therefore, we propose the following hypothesis: $H_{0}$ : Brand awareness is positively related to beer Brand Equity.

Perceived Quality is the second dimension of Brand Equity. Perceived quality is defined by the Marketing Science Institute (Leuthesser, 1988) as the associations and behaviors of the consumers that lead branded products to obtain higher volumes and margins than those that would be obtained without the brand. Consumers' Perceived Quality of a determinate brand is due to their subjective perception process, involved in the decision- making process. Following Zeithaml (1988), the perceived quality is the global outcome of the experience of the different sensory stimuli which could be used as a global assessment of the competitive quality of a brand. A high perceived quality occurs when potential consumers recognize the differentiation and superiority of a brand in relation with other competitor brands. Therefore, a high level of perceived quality in a specific beer brand would influence consumers' purchasing decision. Therefore, we propose the following research hypothesis: $H_{1}$ : Perceived quality is positively related to beer Brand Equity 
Brand Equity is largely supported by brand associations -or brand image-. The brand associations consist in multiple images, ideas, instances or facts that establish a solid network of brand knowledge (Yoo et al., 2000); and are formed as a result of the consumer's brand belief (Aaker, 1991). Therefore, consumers' favorable brand images and beliefs will influence and affect their purchasing behavior and the choice of a brand or even a product. So, consumers' positive and favorable images related to a specific beer brand would increase their beer Brand Equity. So, the following research hypothesis is posed: $\mathrm{H}_{2}$ : Brand image is positively related to beer Brand Equity

Finally, the equity of a brand is largely created by brand loyalty. Aaker (1996) and Keller (1993) suggest that the value or equity of a brand or product depends on the number of people who are purchasing it regularly. Moreover, brand loyalty has been found to have a direct and positive role in affecting Brand Equity (Atilgan et al., 2005). Therefore, we propose that beer brand loyalty enhances the Brand Equity. Therefore, we will propose the following hypothesis: $\mathrm{H}_{3}$ : Brand loyalty is positively related to beer Brand Equity.

Consumer-based Brand Equity has been considered as a condition or prerequisite for the election or preference of a brand, which subsequently affects the purchase intention. Several studies point out the positive relationship between the dimensions of Brand Equity, brand preference and the purchase intention (Vakratsas and Ambler, 1999; Myers, 2003). Thus, we propose the following research hypothesis: $H_{4}:$ Brand equity is positively related to beer brand purchase intention

Additionally, Brand Equity is likely to influence the willingness that consumers have to pay a premium price for a product or brand (Arvidsson, 2006). Brand equity in commercial brand names influences consumer response to the increase in the price of the product, so that their response to a price increase is more inelastic (Keller, 2003; Hoeffler and Keller, 2003). Moreover, several authors have demonstrated that consumers are willing to pay a higher price for those brands that have positive brand associations, or otherwise provide with higher value (Erdem et al., 2002; Netemeyer et al., 2004). Therefore, we propose the following hypothesis: $\mathrm{H}_{5}$ : Brand equity has a positive effect on consumer willingness to pay a premium price. 
Figure 1: Conceptual Proposed model

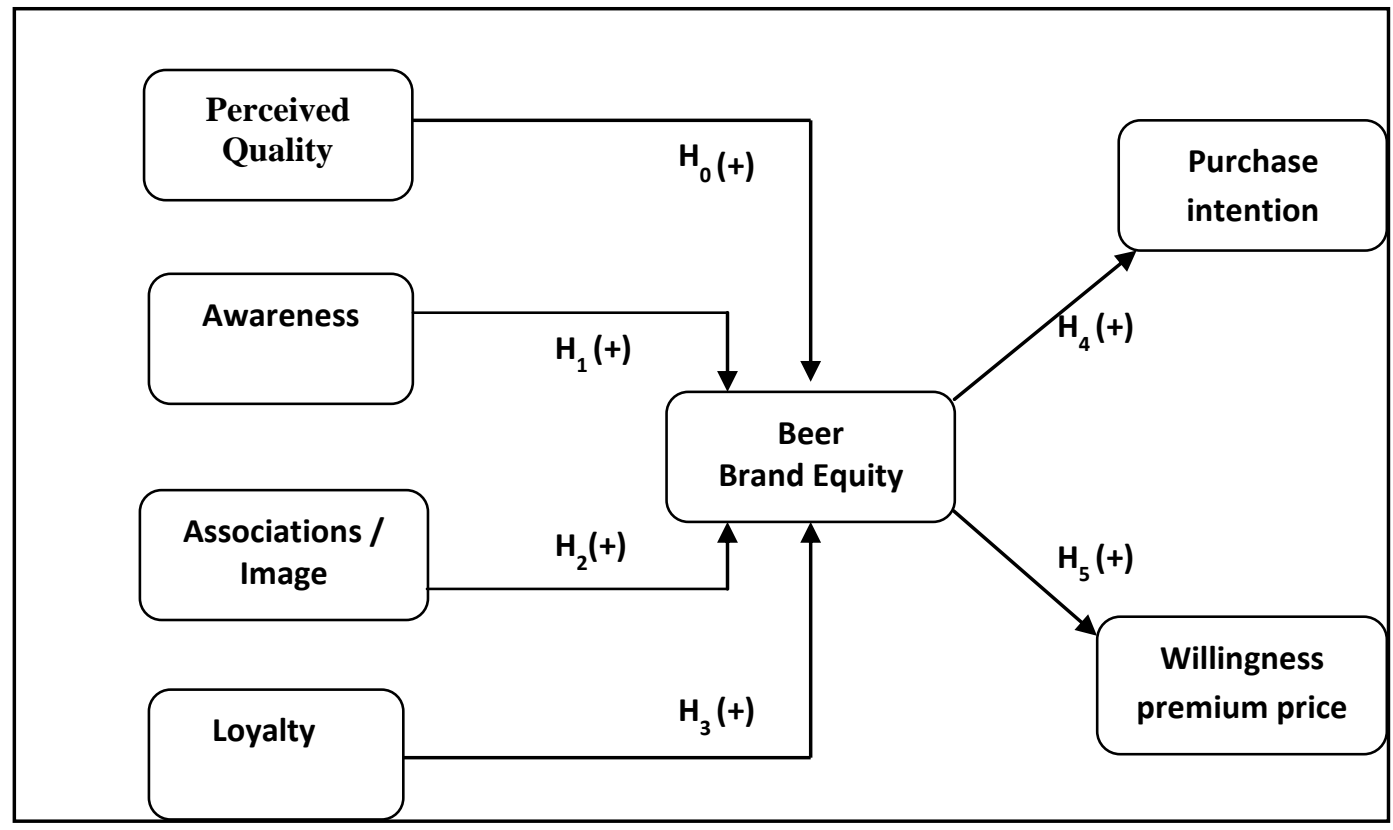

\section{Methodology}

\subsection{Product and brand selection}

We selected beer as product category because it is widely popular in Europe and in Spain, and because beer consumption does not depend on consumer's age, education, income or social status. So, standard beer quality and its characteristics enable consumers to have a stable preference structure.

In our research, for analyzing Brand Equity we selected six brands of the same product category -beer- as it was explained before. For that purpose, we followed some criteria. First one is that brands selected for the study were well-known, popular and available for Spanish consumers at the point of sale. This question must be taken into consideration, because of the presence of different beer brands in the market, with different levels of knowledge and familiarity among consumers, must be considered for the reliability of measurement scales (Parameswaran and Yaprak, 1987). For that purpose, brands chosen were available in the Spanish market and have high recognition and notoriety among consumers. The second criterion that was taken into account when selecting beer brands was the requirement to present relevant differences among them in areas such as sale price and the marketing strategy followed by the brewery company. Third and last criterion considered was the origin of the beer brand. So finally three Spanish brands were chosen, one with a strong regional presence,-Estrella Galicia- and other two brands with broad national 
implantation -Mahou and Cruzcampo. On the other hand, there were selected three brands of imported beer, two of them with a European origin -Heineken and Carlsberg- and one last beer brand with a more remote origin and provenance Coronita. In conclusion, we can state that the brands selected are well- known and familiar to the Spanish population.

\subsection{Variables and measurement scales}

The measurement of variables was carried out using a Likert-type scale of 5 points, with 1 being strongly disagree and 5 strongly agree. When measuring the dimensions of Brand Equity we considered a fully detailed review of the literature on this topic. First, in order to measure brand awareness, we used five items proposed by Yoo et al. (2000) and by Netemeyer et al. (2004), which refer to the general knowledge the consumer has about a brand and to their ability to distinguish and recognize a brand compared to other competitive brands. In second place, in order to evaluate perceived quality, we used four items previously used by Pappu and et al. (2006), which assess the perceived quality without regarding the attributes specific to a particular product category. To assess brand associations, we used different items that were previously used by different researchers (Aaker, 1996; Pappu et al., 2005). For measuring brand loyalty, we use the scale proposed by Yoo et al., (2000), which analyzes whether the consumer is considered loyal to a particular brand and if the brand is its first option, even if he would not buy other brands when this brand is not available at the point of sale. In order to assess the overall Brand Equity we used the items proposed by Yoo et al. (2000), since they will incorporate the additional value of a product or a brand, because of their brand names. Finally, in order to evaluate consumers' willingness to pay a premium price for a brand and consumers' purchase intention, we used items proposed by Netemeyer et al. (2004). Table 1 shows measurement scales and indicators used, as well as latent variables to be analyzed.

Table 1: Measurement scales, variables and reflective indicators used for measuring Brand Equity

\begin{tabular}{|l|l|}
\hline \multicolumn{1}{|c|}{ Variables } & \multicolumn{1}{c|}{ Indicators } \\
\hline $\begin{array}{l}\text { Awareness } \\
\text { Yoo et al. (2000), Netemeyer } \\
\text { et al. (2004) }\end{array}$ & $\begin{array}{l}\text { Aw1: I have heard about and I know brand X } \\
\text { Aw2: I am able to recognize brand X easily from among other } \\
\text { competitive brands }\end{array}$ \\
\hline $\begin{array}{l}\text { Perceived Quality } \\
\text { Qoo et al. (2000); Pappu, }\end{array}$ & $\begin{array}{l}\text { PQal1: Brand X offers excellent quality products } \\
\text { PQal2: Brand X offers reliable and trustworthy products }\end{array}$ \\
\hline $\begin{array}{l}\text { Associations/ Image } \\
\text { Lassar et al. (1995), Aaker }\end{array}$ & $\begin{array}{l}\text { Aso1:Within the beer market, I believe that brand X is a } \\
\text { good purchase }\end{array}$ \\
\hline
\end{tabular}




\begin{tabular}{|l|l|}
\hline $\begin{array}{l}\text { (1996), Netemeyer et al. } \\
\text { (1994) }\end{array}$ & $\begin{array}{l}\text { Aso2:Brand X provides a high value in relation with the } \\
\text { price you pay for it } \\
\text { Aso3: Brand X is interesting } \\
\text { Aso4: The company that makes brand X has credibility }\end{array}$ \\
\hline $\begin{array}{l}\text { Loyalty } \\
\text { Yoo et al. (2000) }\end{array}$ & $\begin{array}{l}\text { Loy1: If I buy beer, X would be my first purchase option } \\
\text { Loy2: I would not buy other brands of beer if brand X } \\
\text { was available at the point of sale }\end{array}$ \\
\hline $\begin{array}{l}\text { Overall Brand Equity } \\
\text { Yoo et al. (2000) }\end{array}$ & $\begin{array}{l}\text { Be1:.It makes sense to buy brand X instead of others } \\
\text { available in the market } \\
\text { Be2: Although there were other brands of beer as good as } \\
\text { X, I would rather buy the brand X }\end{array}$ \\
\hline $\begin{array}{l}\text { Purchase Intention } \\
\text { Netemeyer et al. (2004) }\end{array}$ & $\begin{array}{l}\text { Int1: I would buy Brand X beer } \\
\text { Int2 Definitively, I would consider buying Brand X beer } \\
\text { Int3: I am likely to buy Brand X beer }\end{array}$ \\
\hline $\begin{array}{l}\text { Willingness to pay a } \\
\text { premium price } \\
\text { Netemeyer et al. (2004) }\end{array}$ & $\begin{array}{l}\text { Pre1: I am willing to pay a higher price for brand X than } \\
\text { other brands of beer } \\
\text { Pre2 I am willing to pay much more for brand X than } \\
\text { other brands of beer }\end{array}$ \\
\hline
\end{tabular}

\subsection{Sampling and fieldwork}

In order to obtain the information we conducted an on-line questionnaire during the month of March 2012. A total of five questionnaires were developed -one questionnaire per brand-, with the same structure and the same questions. Questionnaires were sent randomly to people residing in Spain. It should be remarked that each one of the questionnaires where responded by a single potential consumer, about one beer brand that was chosen randomly. Finally, there were obtained 346 valid responses. The sampling error was of 5.96\%. Regarding the structure of the questionnaire, it consisted of several parts. The first part was related to the different dimensions and consequences of beer Brand Equity. Finally, we incorporated some questions concerning socio-demographical and economic variables. A sample description is summarized in Table 2. 
Table 2: Sample description

\begin{tabular}{|l|l|r|r|}
\hline \multicolumn{2}{|l|}{ Variables } & Frequency & Percentage \\
\hline \multirow{4}{*}{$\begin{array}{c}\text { Frequency of } \\
\text { Consumption }\end{array}$} & Daily consumption & 29 & 8.38 \\
\cline { 2 - 4 } & Once per week & 88 & 24.43 \\
\cline { 2 - 4 } & Several times per week & 85 & 24.56 \\
\cline { 2 - 4 } & Ocassionaly & 128 & 37.00 \\
\cline { 2 - 4 } & Several times per year & 16 & 5,63 \\
\cline { 2 - 4 } & Total & $\mathbf{3 4 6}$ & $\mathbf{1 0 0 . 0}$ \\
\hline \multirow{4}{*}{ Age } & From 18 to 23 years & 159 & 45.95 \\
\cline { 2 - 4 } & $24-29$ & 70 & 20.23 \\
\cline { 2 - 4 } & $30-39$ & 54 & 15.60 \\
\cline { 2 - 4 } & $40-49$ & 37 & 10.69 \\
\cline { 2 - 4 } & $>50$ & 26 & 7.53 \\
\cline { 2 - 4 } & Total & $\mathbf{3 4 6}$ & $\mathbf{1 0 0 . 0}$ \\
\hline \multirow{4}{*}{ Gender } & Male & 214 & 61.85 \\
\cline { 2 - 4 } & Female & 132 & 38.15 \\
\cline { 2 - 4 } & Total & $\mathbf{3 4 6}$ & $\mathbf{1 0 0 . 0}$ \\
\hline
\end{tabular}

\subsection{Data analysis and techniques}

In this research we carry out a structural covariance analysis. This analysis identifies not only the factors that are explained by the different items or indicators, but also the weight of each one of the on Brand Equity, as wells as its consequences in consumer behavior - disposition or willingness to pay a premium price and the purchase intention. For that purpose, we used Structural Equation Modeling (SEM), with Amos 18.0.

\section{Results}

\subsection{Structural model analysis}

In order to analyze the measurement model, there was carried out a confirmatory factor analysis, in order to validate reliability and statistical validity. The results showed an adequate specification of the proposed factorial structure. In relation with the analyses of internal consistency and reliability, Cronbach Alpha, Composite reliability coefficients and analysis of the extracted variance exceeded (AVE) were calculated (Table 3). We obtained Cronbach Alpha acceptable values of 0.7, 0.8 and 0.9, as suggested (Anderson and Gerbing, 1988; Hair et al., 2006).

Following previous literature, composite reliability coefficients that exceed a value of 0.5 confirm the internal reliability of the construct considered (Bagozzi and $\mathrm{Yi}, 1989)$. In relation with the analysis of extracted variance exceeded, that 
should have higher value than 0.5 , we also obtain acceptable values for all constructs (Hair et al., 1999). We have also analyzed the validity of scales, checking the convergent and discriminant validity. In this regard, all of the indicators presented significant standardized lambda coefficients in excess of 0.50 . This verifies the convergent validity of the scales (Fornell and Larcker, 1981; Lévy, 2001; Diamantopoulos and Siguaw, 2006).

Table 3: Factor loadings of latent variables and Indicators of Internal Consistency and Reliability

\begin{tabular}{|c|c|c|c|c|c|}
\hline VARIABLES & Indicators & $\begin{array}{c}\text { Standarized } \\
\text { Loadings }\end{array}$ & $\begin{array}{c}\text { Alpha } \\
\text { Cronbach } \\
\end{array}$ & $\begin{array}{l}\text { Composite } \\
\text { Reliability } \\
\end{array}$ & AVE \\
\hline $\begin{array}{l}\text { Brand } \\
\text { Awareness }\end{array}$ & $\begin{array}{l}\text { Aw1 } \\
\text { Aw2 }\end{array}$ & $\begin{array}{l}0.711 \\
0.755\end{array}$ & 0.678 & 0.699 & 0.537 \\
\hline $\begin{array}{l}\text { Perceived } \\
\text { Quality }\end{array}$ & $\begin{array}{l}\text { PQal1 } \\
\text { PQal2 } \\
\end{array}$ & $\begin{array}{l}0.910 \\
0.881 \\
\end{array}$ & 0.878 & 0.890 & 0.802 \\
\hline $\begin{array}{l}\text { Brand } \\
\text { Associations }\end{array}$ & $\begin{array}{l}\text { Aso1 } \\
\text { Aso2 } \\
\text { Aso3 } \\
\text { Aso4 }\end{array}$ & $\begin{array}{l}0.839 \\
0.826 \\
0.863 \\
0.781\end{array}$ & 0.881 & 0.896 & 0.685 \\
\hline Loyalty & $\begin{array}{l}\text { Loy1 } \\
\text { Loy2 }\end{array}$ & $\begin{array}{l}0.957 \\
0.950\end{array}$ & 0.949 & 0.952 & 0.909 \\
\hline Brand Equity & $\begin{array}{l}\mathrm{Be} 1 \\
\mathrm{Be} 2 \\
\end{array}$ & $\begin{array}{l}0.956 \\
0.964\end{array}$ & 0.943 & 0.947 & 0.931 \\
\hline Purchase Intention & $\begin{array}{l}\text { Int1 } \\
\text { Int2 } \\
\text { Int3 }\end{array}$ & $\begin{array}{l}0.927 \\
0.948 \\
0.953\end{array}$ & 0.824 & 0.959 & 0.888 \\
\hline $\begin{array}{l}\text { Willingness to pay } \\
\text { premium price }\end{array}$ & $\begin{array}{l}\text { Pre1 } \\
\text { Pre2 }\end{array}$ & $\begin{array}{l}0.983 \\
0.796\end{array}$ & 0.875 & 0.887 & 0.799 \\
\hline
\end{tabular}

According to the results obtained for the structural modeling adjustment, ChiSquare, is significant, so that it could be considered a reliable indicator of model fit (Bollen, 1989). Other absolute measures of modeling adjustment (Goodness of Fit Index and Root Mean Square Error of Approximation) show good results, given that the former approach near a 0.9 value and the later comes near a 0.05 value. The measures of incremental fit also indicate a proper fit, considering that the Incremental Fit Index, Tucker-Lewis Index and the Comparative Fit Index indicate values superior $\tan$ 0.9. Moreover, the coefficients presented a good ratio with each of the underlying factors $\left(\mathrm{R}^{2}=0.914\right)$. 
Table 4: Structural Modelling Adjustment Indexes

\begin{tabular}{|l|c|}
\hline \multicolumn{2}{|l|}{ Absolut Fit Measures } \\
\hline Chi-Square & 67.565 \\
\hline Degrees of Freedom & 0.013 \\
\hline Significant Level & 0.960 \\
\hline Goodness of Fit Index (GFI) & 0.044 \\
\hline $\begin{array}{l}\text { Root Mean Square Error of } \\
\text { Approx (RMSEA) }\end{array}$ \\
\hline $\begin{array}{l}\text { Adjusted Goodness of Fit } \\
\text { Index (AGFI) }\end{array}$ \\
\hline Incremental Fit Measures \\
\hline Normed Fit Index (NFI) & 0.929 \\
\hline Incremental Fit Index (IFI) & 0.814 \\
\hline Tucker-Lewis Index (TLI) & 0.926 \\
\hline Comparative Fit Index (CFI) & 0.881 \\
\hline Parsimony Measures & 0.921 \\
\hline Normed Chi-Square & 1.536 \\
\hline
\end{tabular}

\subsection{Discussion}

We aimed to analyze the sources and consequences of beer Brand Equity in a specific European mature market. Considering the standarized coefficients, some results must be highlighted (Table 5). One major finding is that as previously hypothesized all relationships of Brand Equity and its sources and consequences are significantly positive. Thus, it can be stated that the higher beer brand awareness, perceived quality, brand loyalty or better beer brand image, the higher the Brand Equity for consumers.

Other relevant finding is the beer brand associations or brand image is the source with a higher loading $\left(\beta_{35}=0.835^{* *}\right)$, followed by perceived quality $\left(\beta_{25}=0.700^{* *}\right)$ and brand loyalty $\left(\beta_{45}=0.668 * *\right)$. Our results show the smaller influence of brand awareness $\left(\beta_{15}=0.212 * *\right)$ on Brand Equity. Hence, in terms of the effect size, the beer brand image seems to contribute the most to the formation of Brand value from the consumers' standpoint. Additionally, it should be also highlighted that the variable beer brand awareness exerts the lower influence on consumers' Brand Equity. The reason is maybe that all the considered beer brands are already popular and Spanish consumers are familiar to them and able to recognize them. Finally, and regarding the beer Brand Equity consequences, we found a positive significant relationship in the expected direction $\left(\beta_{56}=0.908^{* *}, \beta_{57}=0.718^{* *}\right)$ So, it can be 
stated that the higher beer Brand Equity the higher purchase intention and the greater disposition to pay a premium price for this specific beer brand.

Table 5: Causal relationships

\begin{tabular}{|l|c|}
\hline \multicolumn{1}{|c|}{ Relations between latent variables } & $\begin{array}{c}\text { Standarized } \\
\text { Coefficients }(\mathbf{n}=\mathbf{3 4 6})\end{array}$ \\
\hline Brand Awareness $\rightarrow$ Brand Equity & $\beta_{15}=0.212^{* *}$ \\
\hline Perceived Quality $\rightarrow \quad$ Brand Equity & $\beta_{25}=0.700^{* *}$ \\
\hline Brand Associations $\rightarrow \quad$ Brand Equity & $\beta_{35}=0.835^{* *}$ \\
\hline Loyalty $\rightarrow$ Brand Equity & $\beta_{45}=0.668^{* *}$ \\
\hline Brand Equity $\rightarrow$ Purchase Intention & $\beta_{56}=0.908^{* *}$ \\
\hline $\begin{array}{l}\text { Brand Equity } \rightarrow \text { Willingness to pay } \\
\text { premium price }\end{array}$ & $\beta_{57}=0.718^{* *}$ \\
\hline $\begin{array}{l}* * \text { significant }(\boldsymbol{p}<0.05) ; * \\
\boldsymbol{R}^{2}(\boldsymbol{p}<\mathbf{0 . 1})\end{array}$ Brand Equitv $)=0.914$ & \\
\hline
\end{tabular}

We accept all the proposed research hypotheses, since the estimated model provides strong support for all of them. Considering the results obtained we can state that the hypothesis $\mathrm{H}_{0}$ : Brand awareness is positively related to beer Brand Equity should be accepted. In relation with hypothesis $H_{1}$ : Perceived quality is positively related to beer Brand Equity, it should also be accepted, since perceived quality shows a significant positive effect on beer Brand Equity. Regarding the hypotheses $\mathrm{H}_{2}$ : Brand associations are positively related to beer Brand Equity and $H_{3}$ : Brand loyalty is positively related to beer Brand Equity, both of them are accepted. As for the consequences of brand equity in response and consumer behavior, we can remark that hypothesis $\mathrm{H}_{4}$ : Brand equity is positively related to consumer purchase intention is also accepted. And finally, our research also verifies that the greater Brand Equity, the greater willingness to pay a premium price for the beer brand. Therefore, we can state that hypothesis $H_{5}$ : Brand Equity is positively related to consumer willingness to pay a premium price, is accepted.

Table 6: Test of research proposed hypotheses

\begin{tabular}{|l|l|}
\hline Research proposed hypotheses & Results \\
\hline $\begin{array}{l}\mathrm{H}_{0}: \quad \text { Brand Awareness is positively related to Beer } \\
\text { Brand Equity }\end{array}$ & Accepted \\
\hline
\end{tabular}




\begin{tabular}{|l|l|}
\hline $\begin{array}{l}\mathrm{H}_{1}: \text { Perceived Quality is positively related to Beer } \\
\text { Brand Equity }\end{array}$ & Accepted \\
\hline $\begin{array}{l}\mathrm{H}_{2}: \text { Brand Associations are positively related to Beer } \\
\text { Brand Equity }\end{array}$ & Accepted \\
\hline $\begin{array}{l}\mathrm{H}_{3}: \text { Brand Loyalty is positively related to Beer Brand } \\
\text { Equity }\end{array}$ & Accepted \\
\hline $\begin{array}{l}\mathrm{H}_{4}: \text { Brand Equity is positively related to Beer Purchase } \\
\text { Intention }\end{array}$ & Accepted \\
\hline $\begin{array}{l}\mathrm{H}_{5}: \text { Brand Equity is positively related to the willingness to } \\
\text { pay a premium price }\end{array}$ & Accepted \\
\hline
\end{tabular}

So, as far as the present empirical research is concerned, focused in the Spanish beer market, the brand awareness, beer brand perceived quality, the beer brand image and brand Loyalty have a significant positive influence on beer Brand Equity, whereas consumers' purchase intention and their willingness to pay a premium price for a specific beer brand are clear consequences of the beer brand value.

Figure 2: Final Structural Model

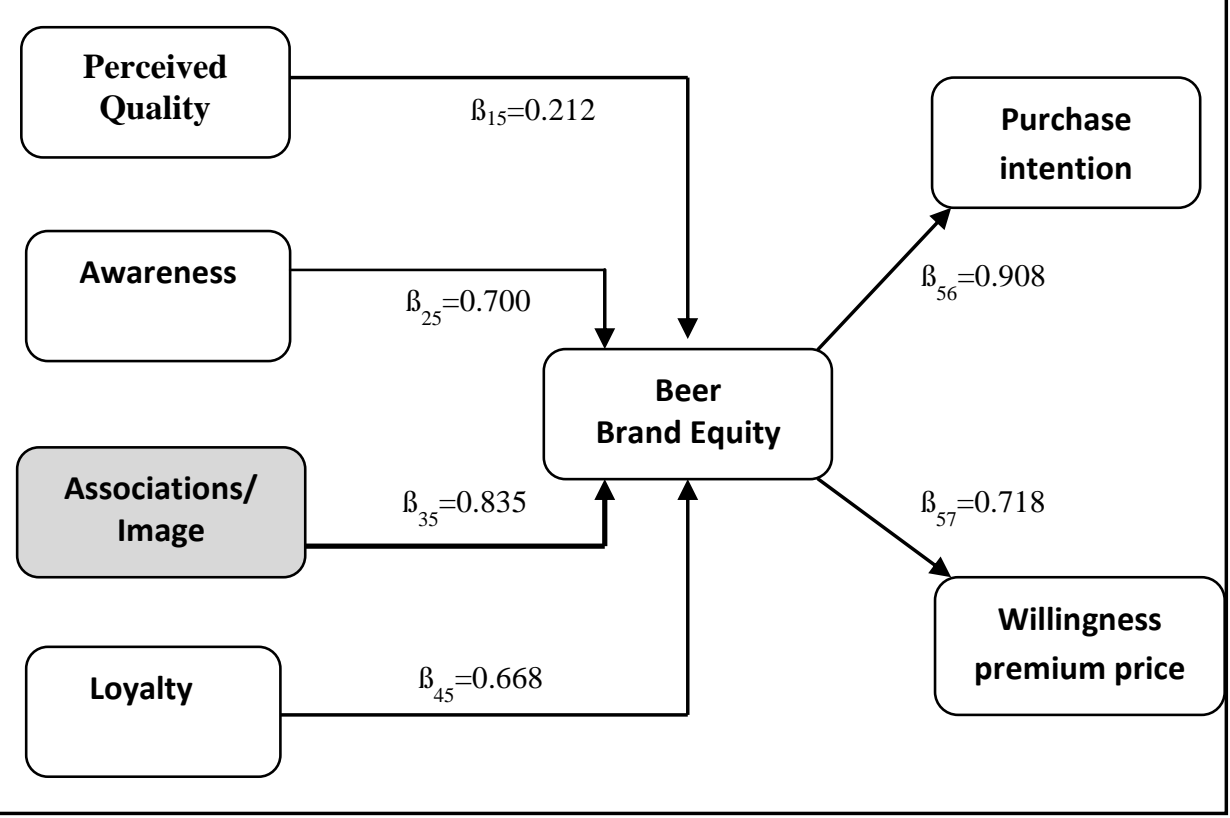




\section{Conclusions}

Brand equity has received continuous attention from researchers and marketing managers and there is great abundance of models and concepts related to Brand Equity, however there are few studies based on empirical data on the brewery sector. The present study entails a detailed and empirical analysis of the sources of beer Brand Equity and their impact on consumer behavior. This research aimed to test the applicability of the Aaker's Brand Equity model, as the most common and well accepted framework in a specific consumption sector and market.

Our findings support the customer-based Aaker's Brand Equity model. Thus, the initially proposed beer Brand Equity sources -brand awareness, perceived quality, brand associations and loyalty- show a significant and positive influence on beer Brand Equity. Among these dimensions, the beer brand image means the higher contribution. So, the mentioned variables should be considered in the management of brewery companies, in order to maintain or improve consumer-based Brand Equity.

Taking into consideration the relevance of Brand Equity, marketing strategies in the brewery sector - should be focused in creating, enhancing and managing Brand Equity; comprising marketing strategies in order to strengthen brand image, as the most important source of Brand Equity. That is, beer companies need to put special emphasis on the creation and development of beer brand image through communication or advertising campaigns, in order to generate a positive and favorable brand image, given that is the main key variable in the creation of Brand Equity from consumers' viewpoint. Moreover, as loyalty is other relevant variable, it appears reasonable to use it more intensely to create a link with consumers. In this sense, social networks have proven to be an effective communication channel for developing brand loyalty by creating virtual communities of loyal consumers. Therefore, brewery companies should adopt and incorporate customer-centered orientation, in order to increase brand loyalty to their beer brands.

As the main limitation of this research should point out, the specific country where the research was conducted. This fact gives a provisional character to the conclusions reached, and we understand that for this reason it is not possible to broadly generalize our conclusions. We consider that the present research provides an good approach to the brewery European market, despite future research should include some other countries and markets, in order to analyze whether the obtained results may be generalized. Second, we should address other interesting dimensions of Brand Equity that have been proposed in the literature, but we have not addressed in this study, such as the country-of-origin, in order to improve the proposed Brand Equity model. Finally, our study is focused in one unique product 
category -beer-, as future research guidance some other food or beverage products should be considered.

\section{References}

Aaker, D. (1991), Managing Brand Equity Capitalizing on the Value of Brand Name, The Free Press, New York.

Aaker, D. (1996), "Measuring Brand Equity Across Products and Market”, California Management Review, 38 (3), pp. 102-120.

Aaker, D. and Keller, K.L. (1990), "Consumer Evaluations of Brand Extensions, Journal of Marketing”, 54, pp. 27-41.

Agarwall, M. and Rao, V. (1996), “An Empirical Comparison of Consumer-Based Measures of Brand Equity”, Marketing Letters, 7(3), pp. 237-247.

Ambler, T. (2003), Marketing and the Bottom Line, 2nd Ed. FT Prentice Hall, London.

Anderson, J. and Gerbing, D. (1988), "Structural equation modelling in practice: A review and recommended two step approach", Psychological Bulletin, 103(3), pp. 411-423.

Arvidsson, A. (2006), "Brand Value", Journal of Brand Management, 13 (2/3), pp. 237-248.

Atilgran, E., Aksoy, S. and Akinci, S. (2005), "Determinants of the Brand Equity: A Verification Approach in the Beverage Industry in Turkey", Marketing Intelligence and Planning, 23 (2/3), pp. 237-248.

Bagozzi, P. and Yi, Y. (1989), "On the Use of Structural Equation Models in Experimental Designs", Journal of Marketing Research, 26, pp. 271-84.

Bollen, K. (1989), "Structural Equations with Latent Variables", Villey Series in Probability and Mathematical Statistic, John Wiley and Sons, New York.

Carpenter, G., Glazer, R. and Nakamoto, K. (1994), "Meaningful brands from meaningless differentiation: the dependence of irrelevant attributes", Journal of Marketing Research, 31, pp. 339-350.

Chen, A. ( 2001), "Using free association to examine the relationship between the characteristics of Brand associations and Brand Equity", Journal of Product and Brand Management, 10 (6/7), pp. 439-44.

Diamantopoulos A, and Siguaw, J. (2006), "Formative versus Reflective Indicators in Organizational Measure Development: A comparison and Empirical Illustration", British Journal of Measure Development, 17 (4), pp. 263-282.

Erdem, T., Swait, J. and Louviere, J. (2002), "The Impact of Brand Credibility on Consumer Price Sensivity", International Journal of Research in Marketing, 19, pp. 1- 19.

Faircloth, J., Capella, L. and Alford, B. (2001), "The effect of Brand attitude and Brand image on Brand Equity", Journal of Marketing Theory and Practice, 9(3), pp. 61-75.

Fornell, C. and Larcker, D. (1981), "Evaluating structural equation models with unobservable variables and measurement error", Journal of Marketing Research, 18, pp. 30-50.

Hair, J., Anderson, R., Tatham, R. and Black, W. (1999), Analisis Multivariante., Prentice Hall, Madrid.

Hair, J., Black, B., Babin, B., Anderson, R. and Tatham, R. (2006), Multivariate Data Analysis, $6^{\text {a }}$ Ed., Prentice Hall, Upper Saddle River.

Hoeffler, S. and Keller, K.L. (2003), "The Marketing Advantages of Strong Brands", Brand Management, 10 (6), pp. 421-445. 
Hoyer, W. (1990), "The effects of brand awareness on choice of a common, repeatpurchase product", Journal of Consumer Research, 17 (2), pp. 141-8.

Kalra, A. and Goodstein, R. (1998), "The impact of advertising positioning strategies on consumer price sensitivity", Journal of Marketing Research, 35, pp. 210- 224.

Keller, K. (1993), "Conceptualizing, Measuring and Managing Customer-Based Brand Equity", Journal of Marketing, 57, pp. 1- 22.

Keller, K. (2003), Strategic Brand Management: Building, Measuring and Managing Brand Equity, 2nd Ed., Prentice Hall, Englewood Cliffs, NJ.

Keller, K. and Lehmann, D. (2003), "How do Brands Create Value?", Marketing Management, 23, pp. 27-31.

Kotler, P. (2000), Marketing Management: Analysis, Planning, Implementation and Control, $10^{\text {th }}$ Ed., Prentice- Hall, Englewood Cliffs, NJ.

Leuthesser, L. (1988), Defining, Measuring and Managing Brand Equity Report, Marketing Science Institute, Cambridge, MA.

Lèvy Mangin, J. (2001), Modelizaciòn y Programaciòn structural con Amos, Editorial Erica, Madrid.

Malhotra, N., Peterson, M. and Kleiser, S. (1999), "Marketing Research: A State-of-theArt Review and Directions for the Twenty-First Century", Journal of the Academy of Marketing Science, 27 (2), pp. 160-183.

Mohd, N., Nasser, M. and Mohamad, O. (2007), "Does Image of Country-of-origin Matter to Brand Equity?", Journal of Product and Brand Management, 16 (1), pp. 3848.

Myers, C.A. (2003), "Managing brand equity: a look at the impact of attributes", Journal of Product and Brand Management, 12 (1), pp. 39-51.

Netemeyer, R., Krishnan, B., Pullig, C., Wang, G., Yaggi, M., Dean, D., Ricks, J. and Wirth, F. (2004), "Developing and Validating Measures of Facets of Customer-Based Brand Equity", Journal of Business Research, 57, pp. 209-224.

Parameswaran, R. and Yaprak, A . (1987), "A Cross-National Comparison of Consumer Research Measures", Journal of International Business Studies, 18 (1), pp. 35-49.

Pappu, R., Quester, P. and Cooksey, R. (2005), "Consumer-based Brand Equity: Improving the Measurement. Empirical Evidence", Journal of Product and Brand Management, 14 (3), pp. 143-154.

Rio, A., Vazquez, R. and Iglesias, V. (2001), "The effects of Brand Associations on consumer response", Journal of Consumer Marketing, 18 (5), pp. 410-25.

Simon, C. and Sullivan, M. (1993), "The measurement and determinants of Brand Equity: A financial approach", Marketing Science, 12 (1), pp. 28-53.

Sriram, S., Balachander, S. and Kalwani, M. (2007), "Monitoring the Dynamics of Brand Equity Using Store- Level Data", Journal of Marketing, 71, pp. 61-78.

SteenKamp, J. and Van Trijp, H. (1991), "The Use of LISREL in the Validating Marketing Constructs", International Journal of Research in Marketing, 8, pp. 283-299.

Thalassinos, I.E. and Zampeta, V. (2012), "Corporate Governance and Globalization Affect the Administrative Structure of the Shipping Industry", Journal of Global Business and Technology, Vol. 8(2), 48-58.

Tong, X. and Hawley, J.(2009), "Creating Brand Equity in the Chinese clothing market: The effect of selected marketing activities on Brand Equity dimensions", Journal of Fashion Marketing and Management, 13 (4), pp. 566-581. 
Vakratsas, D. and Ambler, T. (1999), "How advertising Works: what do we really know?, Journal of Marketing", 63 (1), pp. 26-43.

Washburn, J. and Plank, R. (2002), "Measuring Brand Equity: an evaluation of a consumer-based Brand Equity scale", Journal of Marketing Theory and Practice, 10 (1), pp. 46-61.

Wood, L. (2000), "Brands and Brand Equity: Definition and Management", Management Decision, 38 (9), pp. 662- 669.

Yoo, B. and Donthu, N. (2000), "Developing and Validating a Multidimensional Consumer-based Brand Equity Scale”, Journal of Business Research, 52, pp. 1-14.

Zeithaml, V. (1988), "Consumer Perceptions of Price, Quality and Value: A Means-end Model and Synthesis of Evidence", Journal of Marketing, 52, pp. 2-22.

Zinkhan, G. and Pereira, R. (1994), “An overview on Marketing Strategy and Planning”, International Journal of Research in Marketing, 11, pp. 185-21 